\title{
Properties of a CDP-Diglyceride Hydrolase from Guinea Pig Brain
}

\author{
Harry G. Rittenhouse, Edward B. Seguin, Stephen K. Fisher, and Bernard W. Agranoff \\ Neuroscience Laboratory, Mental Health Research Institute and Department of Biological Chemistry, University of \\ Michigan, 1103 E. Huron, Ann Arbor, Michigan 48109, U.S.A.
}

\begin{abstract}
Enzymatic hydrolysis of the pyrophosphate bond of CDPdiglyceride (CDP-DG), previously shown to occur in bacteria, is demonstrable in mammalian tissues. Activity was enriched in a lysosomal fraction obtained from guinea pig cerebral cortex and was purified 92 -fold relative to the homogenate by a combination of XM-300 ultrafiltration and DEAE-cellulose column chromatography. When incubated with CDP-dipalmitin, the purified enzyme produced stoichiometric amounts of CMP and phosphatidate. dCDP-DG served as a substrate, while ADP-DG was an inhibitor, as were $5^{\prime}$-AMP and 5'-dAMP. CDP-DG hydrolysis was not affected by the presence of excess amounts of CDP-choline, CDP-glycerol, sodium pyrophosphate, or cyclic 3',5'-AMP. Key Words: CDP-diglyceride hydrolase-LysosomesPhosphatidate-Cytidine 5'-monophosphate-Adenosine 5'-monophosphate. Rittenhouse H. G. et al. Properties of a CDP-diglyceride hydrolase from guinea pig brain. J. Neurochem. 36, 991-999 (1981).
\end{abstract}

CDP-diglyceride (CDP-DG; 5'-cytidine diphospho-1,2-diacyl-sn-glycerol) is an obligatory intermediate for the formation of the bacterial phospholipids. In eukaryotic cells, the liponucleotide is the biosynthetic precursor of two classes of phospholipids, the phosphatidylinositols and the phosphatidylglycerols. CDP-DG has been isolated in minute amounts from mammalin liver (Thompson and MacDonald, 1975) and brain (Thompson and MacDonald, 1976) and has been found to be highly enriched in stearate and arachidonate, a pattern which closely resembles that observed in isolated diacylglycerol as well as in the phosphatidylinositols, but not seen in the phosphatidylglycerol series or in isolated phosphatidate (Thompson and MacDonald, 1976).

The low rate of synthesis of CDP-DG and its low steady state content in brain and liver suggest that enzymes involved in its synthesis and degradation may be part of a regulatory mechanism in lipid

Received July 1, 1980; revised September 9, 1980; accepted September 14, 1980.

Address correspondence and reprint requests to $\mathrm{Dr}$. B. W. Agranoff.

The present address of Harry G. Rittenhouse is Abbott Laboratories, Diagnostic Division, Experimental Biology, 90C, N. Chicago, Illinois 60064 . biosynthesis. The demonstration of a bacterial enzyme that catalyzes the hydrolytic cleavage of CDP-DG to yield phosphatidate (PhA) and CMP (Raetz et al., 1972; 1976), raised the possibility that the reaction also occurs in eukaryotic cells, where it could play a role in liponucleotide metabolism. Both the metabolic relationship of CDP-DG to lipids involved in the well-known "phospholipid labeling effect" (Hokin and Hokin, 1955; for reviews, see Michell, 1975; Hawthorne and Pickard, 1979) and current interest in release of arachidonate from tissue lipid stores contributed to interest in this hydrolase. A preliminary account of this work has been presented (Rittenhouse et al., 1980).

\section{MATERIALS AND METHODS}

$\left[5-{ }^{3} \mathrm{H}\right] \mathrm{Cytidine}-5^{\prime}$-monophosphate $(15-30 \mathrm{Ci} / \mathrm{mmol})$ and $\left[1{ }^{14} \mathrm{C}\right]$ acetyl coenzyme $A(50 \mathrm{mCi} / \mathrm{mmol})$ were obtained from Amersham-Searle, Chicago, Illinois. $\left[1-{ }^{14} \mathrm{C}\right]$ -

Abbreviations used: ara-A, Arabinosyl adenosine; ara-C, Arabinosyl cytosine; CDP-DG, $5^{\prime}$-Cytidine diphospho-1,2-diacylsn-glycerol; PhA, Phosphatidate, diacyl-sn-glycerol-3-phosphate; PhI, Phosphatidylinositol. 
Tyramine $(40-60 \mathrm{mCi} / \mathrm{mmol})$ was a product of New England Nuclear Corp., Boston, Massachusetts. $\left[{ }^{3} \mathrm{H}\right]-$ dCDP-diglyceride $(0.23 \mathrm{mCi} / \mathrm{mmol}$, labeled in the cytidine moiety) and unlabeled ADP-diglyceride were the generous gift of Dr. W. Dowhan. Dipalmitoyl-snglycerol-3-phosphate (L- $\alpha$-dipalmitoylphosphatidate), AMP, 2-deoxy AMP, CDP, D-ribose 5'-monophosphate, adenosine $5^{\prime}$-monosulphate, adenosine $5^{\prime}$-monophosphoramidate, tetrasodium pyrophosphate, cyclic $3^{\prime}, 5^{\prime},-$ AMP, adenosine, CMP, IMP, CDP-choline, CDPglycerol, and dipalmitoyl CDP-DG were products of Sigma Chemical Co., St. Louis, Missouri. Arabinosyl cytosine (ara-C), ara-CMP, arabinosyl adenosine (ara-A), and ara-AMP were obtained from P-L Biochemicals Inc., Milwaukee, Wisconsin. $\alpha, \beta$-Methylene ATP and $\beta, \gamma$ methylene ATP were purchased from Miles Laboratories, Inc., Elkhart, Indiana. Adenosine $5^{\prime}$ - $O$-thiomonophosphate was the product of Boehringer-Mannheim Biochemicals, Indianapolis, Indiana. Unlabeled dCDPDG and 1-palmitoyl glycerol-3-phosphate (lysophosphatidate) were obtained from Serdary Research Laboratories, London, Ontario; Triton X-100 from Rohm and Haas Co., Philadelphia, Pennsylvania; Unisil from the Clarkson Chemical Co., Williamsport, Pennsylvania.

\section{Preparation of Subcellular Fractions}

For each experiment, three male guinea pigs (300-350 g) were killed by stunning and exsanguination. Whole brains rostral to the colliculi were removed within 2 min and rinsed in $0.32 \mathrm{M}$-sucrose. The cerebral cortices were then separated from underlying midbrain structures and excess white matter removed with a blunt spatula. The tissue (approximately $1.5-2.0 \mathrm{~g}$ wet weight/brain) was homogenized in a glass homogenizer with 9 volumes of $0.32 \mathrm{M}$-sucrose. Subsequent fractionation of the homogenate was carried out as previously described (Schacht and Agranoff, 1972). The postmitochondrial supernatant was further separated into microsomal $\left(\mathbf{P}_{3}\right)$ and high-speed soluble fractions $\left(S_{3}\right)$ by centrifugation at $105,000 \mathrm{~g}$ for 60 min. Subcellular fractions were resuspended in $0.32 \mathrm{M}-$ sucrose to yield protein concentrations of $2-10 \mathrm{mg}$ protein $/ \mathrm{ml}$.

A subfraction enriched in lysosomes was prepared from the $\mathrm{P}_{2}$ pellet (crude mitochondrial fraction) by the "chemical field method" of Lisman et al. (1978). The mitochondria-enriched fraction was taken as "fraction 1" after low-speed centrifugation of the $P_{2}$ fraction in the presence of succinate. The lysosome-enriched fraction in the present study represented pooled fractions $1-5$ after the second ultracentrifugation step described by Lisman et al. (1978).

\section{Preparation of $\left[{ }^{3} \mathrm{H}\right]$ Cytidine Diphosphodipalmitoyl-sn- Glycerol ([/ H]CDP-Dipalmitin)}

$\left[{ }^{3} \mathrm{H}\right] \mathrm{CMP}-$ morpholidate was prepared by the reaction of $0.5 \mathrm{mmol}$ of [ $\left.{ }^{3} \mathrm{H}\right] \mathrm{C} \mathrm{MP}(350 \mu \mathrm{Ci} / \mathrm{mmol})$ with $2 \mathrm{mmol}$ each of morpholine and of $N, N^{\prime}$-dicyclohexylcarbodiimide, and $\left[{ }^{3} \mathrm{H}\right] \mathrm{CDP}$-dipalmitin was prepared from $0.3 \mathrm{mmol}$ of dipalmitoyl $\mathrm{PhA}$ and an equimolar amount of the resultant labeled CMP morpholidate (Agranoff and Suomi, 1963). After 4 days, the reaction mixture was dried in a rotary evaporator under reduced pressure and dissolved in chloroform/methanol/6 $\mathrm{M}-\mathrm{HCl}(200: 100: 1$, by vol.). The mixture was washed twice with an added aqueous upper phase from which unreacted $\left[{ }^{3} \mathrm{H}\right] \mathrm{CMP}$-morpholidate was removed. The $\left[{ }^{3} \mathrm{H}\right] \mathrm{CDP}$-dipalmitin product was further purified by silica gel chromatography. The lipid extract was applied to a column $(10 \times 1.5 \mathrm{~cm})$ containing $10 \mathrm{~g}$ of Unisil which was treated sequentially with $200-\mathrm{ml}$ volumes of chloroform/pyridine/formic acid (50:30:7, by vol.), chloroform, and chloroform/methanol $(3: 2, \mathrm{v} / \mathrm{v})$. The $\left[{ }^{3} \mathrm{H}\right] \mathrm{CDP}$-dipalmitin was eluted in the latter fraction and dried under reduced pressure. The product was suspended in 1-2 ml of cold water, and an equimolar amount of Tris base was added incrementally with frequent sonication to avoid the possibility of alkaline hydrolysis of the ester bonds. The $\mathrm{pH}$ of the milky suspension was then adjusted to 7.4 with additional Tris if necessary, using narrow-range indicator paper, and then stored at $4^{\circ} \mathrm{C}$. Under these conditions, less than $5 \%$ breakdown occurred over a 2 -month period. Some $10-40 \%$ of the labeled morpholidate was converted to the liponucleotide. Purity of the product was in excess of $95 \%$ as judged by TLC and high-voltage electrophoresis (HVE).

\section{Thin-Layer Chromatography}

Solvent systems employed were: (A) chloroform/ methanol/acetic acid/water (50:25:7:3, by vol.) and (B) chloroform/pyridine/formic acid (50:30:7, by vol.) as described by Raetz et al. (1976). Silica gel G or HPTLC plates (E. M. Merck) were obtained from Brinkman Industries, Des Plaines, Illinois. Lipids were visualized by lipid phosphorus spray (Dittmer and Lester, 1964) or by charring with sulfuric acid reagent (Fewster et al., 1969).

\section{High-Voltage Electrophoresis}

Samples were applied to Whatman No. 1 filter paper in buffer and subjected to HVE at $4000 \mathrm{~V}$ for $30 \mathrm{~min}$ in the same buffer. To follow CMP-morpholidate synthesis, a 0.05 M-sodium tetraborate buffer ( $\mathrm{pH}$ 8.7) was employed. CMP-morpholidate migrated $10 \mathrm{~cm}$, while CMP migrated $14 \mathrm{~cm}$. For enzyme product identification, a pyridine/ acetic acid/water mixture (14:40:356, pH 4.3) was employed. CDP-DG remained at the origin and cytosine and cytidine moved toward the cathode, while CMP and CDP migrated anodally $6 \mathrm{~cm}$ and $9 \mathrm{~cm}$, respectively:

\section{Assay of CDP-DG Hydrolase}

The standard enzyme assay medium contained $0.1 \mathrm{M}$ Tris-maleate buffer ( $\mathrm{pH} 4.8), 0.3 \%$ Triton $X-100(\mathrm{w} / \mathrm{v})$, $0.28 \mathrm{~mm}-\left[{ }^{3} \mathrm{H}\right] \mathrm{CDP}$-dipalmitin $(0.35 \mathrm{mCi} / \mathrm{mmol})$ and $1-150$ $\mu \mathrm{g}$ of enzyme protein in a final volume of $0.1 \mathrm{ml}$. The reaction was initiated by the addition of lipid substrate, which had been sonicated for $15 \mathrm{~s}$. Assays were performed at $37^{\circ} \mathrm{C}$ for $30-60 \mathrm{~min}$, and the reactions terminated by the addition of $1.12 \mathrm{ml}$ of chloroform-methanol $(1: 2, v / v)$. The lipid components of the incubation mixture were then separated from water-soluble products by the further addition of $0.025 \mathrm{ml}$ of $6 \mathrm{M}-\mathrm{HCl}, 0.38 \mathrm{ml}$ of chloroform, and $0.58 \mathrm{ml}$ of $\mathrm{H}_{2} \mathrm{O}$ (Hajra et al., 1968). The two phases were then separated by low-speed centrifugation at room temperature, and $1.0 \mathrm{ml}$ of the clear overlying 
aqueous layer was carefully removed and dried in a counting vial under a stream of $\mathbf{N}_{2}$. Radioactivity was determined after the addition of $1 \mathrm{ml}$ of water and $10 \mathrm{ml}$ of ACS scintillation cocktail (Amersham Searle, Chicago, Illinois). Counting efficiency for ${ }^{3} \mathrm{H}$ was approximately $25 \%$, as determined by an internal standard method. Observed enzyme activity was corrected for the amount of radioactivity present in the aqueous phase of zero time incubations (1.5-3\% of radioactivity initially added).

\section{Assay of Marker Enzymes}

Succinate dehydrogenase (EC 1.3.99.1) was determined by measuring succinate-dependent reduction of 2 ( $p$-iodophenyl) - 3-( $p$ - nitrophenyl - 5 - phenyltetrazolium) chloride (INT), using the procedure of Porteus and Clark (1965). Acetylcholinesterase (EC 3.1.1.7) was determined by the method of Ellman et al. (1961), with the exception that the assays included $10^{-5} \mathrm{M}$-tetraisopropylpyrophosphoramide to inhibit pseudocholinesterase (Hoover et al., 1978). Choline acetyltransferase (EC 2.3.1.6) was determined by the procedure of Fonnum (1975). Monoamine oxidase (EC 1.4.3.4) was determined by the method of Donnelly et al. (1976), using $\left[{ }^{14} \mathrm{C}\right]$ tyramine as substrate. $\beta$-Galactosidase (EC 3.2.1.23) and $\beta$-glucuronidase (EC 3.2.1.31) activities were determined at $\mathrm{pH} 5.0$ spectrophotometrically, as described by Cotman and Matthews (1971), using $p$-nitrophenyl- $O$-D-galactoside and $p$-nitrophenyl-O-D-glucuronide as substrates.

\section{Chemical Determinations}

Protein was determined spectrophotometrically (Geiger and Bessman, 1972), using bovine serum albumin as a standard. To circumvent interference by Triton X-100 or Tris- $\mathrm{HCl}$ buffer, protein was first precipitated by addition of sodium deoxycholate and trichloroacetic acid prior to estimation (Bensadoun and Weinstein, 1976). Total lipid phosphorus was determined by the method of Ames and Dubin (1960).

\section{RESULTS}

\section{Characterization of CDP-DG Hydrolase Activity in Homogenates}

CDP-DG hydrolase activity, as measured by the release of water-soluble radioactivity, was linear with respect to time of incubation for up to $90 \mathrm{~min}$ and with amounts of protein up to $150 \mu \mathrm{g}$ under conditions of partial substrate utilization. Incubation times and amount of enzyme were subsequently maintained so that less than $25 \%$ of the substrate routinely underwent hydrolysis. The addition of Triton X-100, to a final concentration of $0.2-0.3 \%$, stimulated enzyme activity $7-10$-fold (Fig. 1). A broad acidic $\mathrm{pH}$ optimum (4.5-5.0) for enzyme activity was observed in guinea pig cerebral cortex homogenates, under which conditions specific activity was $0.33 \pm 0.11 \mathrm{nmol}$ (s.D.) of watersoluble radioactivity released per min per $\mathrm{mg}$ of protein $(n=7)$.

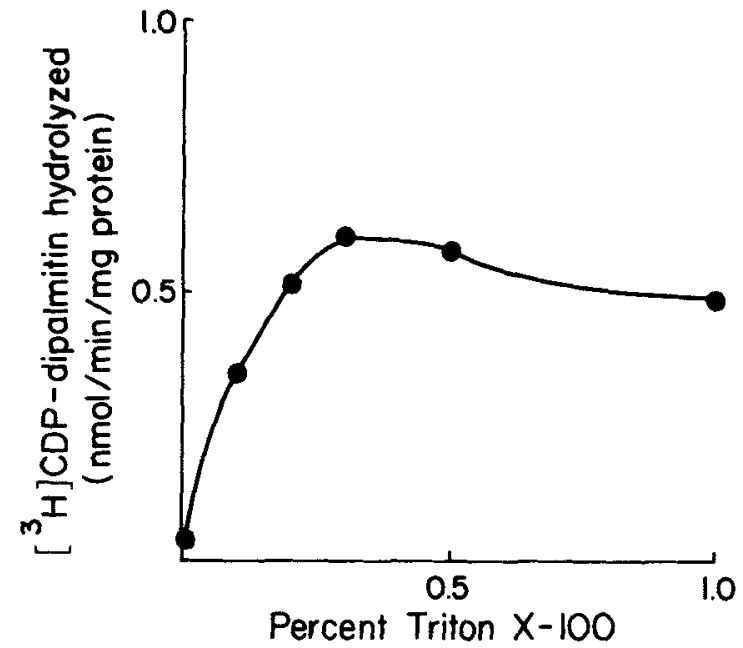

FIG. 1. Effect of Triton $X-100$ on CDP-diglyceride hydrolase activity. Homogenate ( $78.4 \mu \mathrm{g}$ protein) was incubated in the standard incubation medium for $60 \mathrm{~min}$ in the presence of different concentrations of Triton $X-100$, as indicated. The reactions were terminated as described in Materials and Methods, and the amount of water-soluble radioactivity determined.

\section{Subcellular Localization of CDP-DG Hydrolase}

To establish the subcellular site of CDP-DG hydrolase activity, cerebral cortex homogenates were fractionated by differential and sucrose-density centrifugation and the subcellular fractions obtained assessed for cross-contamination, by means of specific marker enzymes. The greatest enrichment of CDP-DG hydrolase was associated with the mitochondrial-lysosomal $\left(\mathrm{P}_{2} \mathrm{C}\right)$ fraction (Table 1$)$. In four separate experiments, this fraction showed an R.S.A. (relative specific activity) of $4.00 \pm 0.48$ when compared to the homogenate. The only other subcellular fraction which exhibited significant enrichment of activity was the synaptosomal fraction (R.S.A. $=1.34 \pm 0.46, n=3$ ). The mitochondrial marker enzymes, succinate dehydrogenase and monoamine oxidase (SDH, MAO), were enriched in the $\mathrm{P}_{2} \mathrm{C}$ fraction to an extent similar to that of CDP-DG hydrolase, although the R.S.A. values for both SDH and MAO were consistently lower than CDP-DG hydrolase in the synaptosomal fraction.

To ascertain whether CDP-DG hydrolase existed in a latent form, the $\mathrm{P}_{2} \mathrm{C}$ fraction was subjected to rapid freeze-thaw treatment. As shown in Table 2, this procedure resulted in an almost quantitative release of CDP-DG hydrolase activity into the soluble fraction, along with two lysosomal marker enzymes, $\beta$-galactosidase and $\beta$-glucuronidase. In marked contrast, the freeze-thaw treatment released little or no SDH or MAO activity from the $\mathrm{P}_{2} \mathrm{C}$ fraction and, in fact, resulted in a significant enrichment of these enzymes in the particulate fraction. Further evidence to suggest a lysosomal localization for CDP-DG hydrolase was obtained 
TABLE 1. Subcellular distribution of CDP-diglyceride hydrolase in guinea pig cerebral cortex

\begin{tabular}{|c|c|c|c|c|c|c|}
\hline \multirow[b]{2}{*}{ Fraction } & \multirow[b]{2}{*}{$\begin{array}{c}\% \\
\text { Protein }\end{array}$} & \multicolumn{5}{|c|}{ Relative specific activity } \\
\hline & & $\begin{array}{l}\text { CDP-diglyceride } \\
\text { hydrolase }\end{array}$ & $\begin{array}{l}\text { Monoamine } \\
\text { oxidase }\end{array}$ & $\begin{array}{c}\text { Succinate } \\
\text { dehydrogenase }\end{array}$ & $\begin{array}{c}\text { Choline } \\
\text { acetyltransferase }\end{array}$ & Acetylcholinesterase \\
\hline \multicolumn{7}{|l|}{$P_{1}$ (crude } \\
\hline$P_{2} A$ (myelin) & 4.02 & 0.37 & 0.21 & 0.09 & 0.26 & 0.58 \\
\hline $\mathrm{P}_{2} \mathrm{~B}$ (synaptosomal) & 5.41 & 1.76 & 0.52 & 0.53 & 2.40 & 0.38 \\
\hline $\mathrm{P}_{2} \mathrm{C}$ (mitochondrial/ & & & & & & \\
\hline lysosomal) & 11.3 & 3.34 & 4.60 & 4.71 & 0.81 & 0.27 \\
\hline $\mathrm{P}_{3}$ (microsomal) & 24.5 & 0.81 & 0.62 & 0.18 & 0.96 & 1.81 \\
\hline$S_{3}$ (soluble) : & 21.2 & 0.30 & 0.00 & 0.00 & 1.07 & 0.30 \\
\hline \% Recovery & 82.1 & 75.0 & 67.0 & 71.1 & 76.0 & 64.3 \\
\hline
\end{tabular}

Subcellular fractions were prepared as described in Materials and Methods and assayed for CDP-diglyceride hydrolase and marker enzyme activities. The relative specific activity is defined as the specific activity of the fraction relative to that of homogenate. Actual specific activities ( $\mathrm{nmol} / \mathrm{mg}$ protein/min) in the homogenate were as follows: CDP-diglyceride hydrolase, 0.27 ; monoamine oxidase, 1.98; succinate dehydrogenase; 14.7; choline acetyltransferase, 0.74; acetylcholinesterase, 82.0. Protein in homogenate was $112 \mathrm{mg} / \mathrm{g}$ wet weight. Results are from one of three experiments that gave similar results.

from subcellular fractionation experiments involving the "chemical field" method, whereby the sedimentation rate of mitochondria is increased by the addition of succinate, facilitating the separation of lysosomes from contaminating mitochondria. Using this technique, lysosomal fractions obtained from the crude mitochondrial fraction $\left(\mathrm{P}_{2}\right)$ were enriched in both $\beta$-galactosidase (R.S.A. $=3.85$ ) and CDP-DG hydrolase (R.S.A. $=3.03$ ) and contained only small amounts of SDH (R.S.A. $=0.68)$. In agreement with the findings of Lisman et al. (1978), they retained significant MAO activity (R.S.A. = 2.06), indicating contamination of the fraction with detached outer mitochondrial membranes.

\section{Purification of CDP-DG Hydrolase}

The $\mathrm{P}_{2} \mathrm{C}$ fraction obtained from three guinea pig cerebral cortices was routinely used as the starting preparation for enzyme purification, and was dialyzed at $4^{\circ} \mathrm{C}$ against at least two 1-liter changes of $1 \mathrm{~mm}$-sodium phosphate buffer ( $\mathrm{pH} 7.4)$ over a $24-\mathrm{h}$ period. The dialysand was rapidly frozen in an
acetone-Dry Ice bath and thawed three times, and the suspension centrifuged at $14,500 \mathrm{~g}$ for $20 \mathrm{~min}$. The supernatant fraction was drawn off carefully in order to avoid contamination of the pelleted debris. More than $85 \%$ of the initial CDP-DG hydrolase activity present was recovered in a soluble form, yielding a 16.5-fold enrichment over the total homogenate (Table 3). Additional freeze-and-thaw treatment of the $\mathrm{P}_{2} \mathrm{C}$ fraction did not release further enzyme activity. The preparation was unstable at $4^{\circ} \mathrm{C}$ or $-20^{\circ} \mathrm{C}$ at this step. The solubilized enzyme was diluted 10-fold with $1 \mathrm{~mm}$-sodium phosphate buffer ( $\mathrm{pH} 7.4$ ) and transferred to an Amicon Model 12 stirred ultrafiltration cell containing an XM-300 membrane (nominal mol. wt. cutoff $>300,000$ ). The solution was concentrated to approximately $1 \mathrm{ml}$ at less than 8 psi. The concentrated enzyme was diluted to $10 \mathrm{ml}$ with $10 \mathrm{~mm}$-Tris-HCl buffer ( $\mathrm{pH} \mathrm{7.4)}$ and concentrated to less than $1 \mathrm{ml}$ by a repetition of the ultrafiltration step. The retentate contained more than $80 \%$ of the applied hydrolase activity and had a specific activity approximately twofold that of the supernatant fraction from the freeze-thaw

TABLE 2. Co-fractionation of CDP-diglyceride hydrolase with lysosomal marker enzymes

\begin{tabular}{lccccc}
\hline & \multicolumn{4}{c}{ Relative specific activity } \\
\cline { 2 - 6 } Fraction & $\begin{array}{c}\text { CDP-diglyceride } \\
\text { hydrolase }\end{array}$ & $\begin{array}{c}\text { Monoamine } \\
\text { oxidase }\end{array}$ & $\begin{array}{c}\text { Succinate } \\
\text { dehydrogenase }\end{array}$ & $\beta$-Galactosidase & $\beta$-Glucuronidase \\
\hline Mitochondrial/ & & & & & \\
lysosomal $\left(\mathrm{P}_{2} \mathrm{C}\right)$ & 4.48 & 4.45 & 4.81 & 4.32 & 5.11 \\
Supernatant & 19.84 & 0.09 & N.D. & 17.3 & 7.54 \\
Particulate & 2.10 & 5.86 & 5.79 & 2.06 & 2.93 \\
\hline
\end{tabular}

Mitochondrial-lysosomal fraction $\left(\mathrm{P}_{2} \mathrm{C}\right)$ was frozen and thawed three times in an acetone-Dry Ice bath and centrifuged at $14,500 \mathrm{~g}$ for $20 \mathrm{~min}$ to obtain particulate and supernatant fractions. CDP-diglyceride hydrolase and marker enzyme activities were then measured in these fractions in addition to initial homogenate. Values expressed are relative specific activities. Actual specific activities in the homogenate ( $\mathrm{nmol} / \mathrm{mg}$ protein/min) were as follows: CDP-diglyceride hydrolase, 0.30 ; succinate dehydrogenase, 18.5 ; monoamine oxidase, $5.2 ; \beta$-glucuronidase, $0.29 ; \beta$-galactosidase, 0.41 . Results are from one of two experiments that gave similar results. N.D., not detectable. 
TABLE 3. Purification of CDP-diglyceride hydrolase from guinea pig cerebral cortex

\begin{tabular}{lcccc}
\hline \multicolumn{1}{c}{ Fraction } & Protein $(\mathrm{mg})$ & $\begin{array}{c}\text { Specific activity } \\
(\mathrm{nmol} / \mathrm{min} / \mathrm{mg} \text { protein) }\end{array}$ & Yield (\%) & Purification \\
\hline Total homogenate & 351 & 0.24 & 100 & 1.0 \\
Mitochondrial $\left(\mathrm{P}_{2} \mathrm{C}\right)$ & 33.3 & 0.98 & 38.9 & 4.1 \\
$\begin{array}{l}\text { Freeze and thaw treatment } \\
\quad \text { (supernatant) }\end{array}$ & 8.24 & 3.96 & 38.8 & 16.5 \\
$\begin{array}{l}\text { Ultrafiltration (XM-300) } \\
\text { retentate }\end{array}$ & 2.35 & 7.38 & 20.6 & 30.9 \\
$\begin{array}{l}\text { DEAE-cellulose } \\
\text { chromatography } \\
\text { (pooled fractions }\end{array}$ & 1.12 & 14.5 & 19.3 & 60.5 \\
$\quad \begin{array}{l}\text { Uand 4) } \\
\text { Ultrafiltration (PM-10) } \\
\text { retentate }\end{array}$ & 0.62 & 22.0 & & \\
\hline
\end{tabular}

See text for experimental details.

treatment. The XM-300 retentate lost more than $25 \%$ activity after storage at $4^{\circ} \mathrm{C}$ for $24 \mathrm{~h}$ in the absence of detergent, but could be stabilized by the addition of Triton X-100 to a final concentration of $0.2 \%$.

Chromatography of the XM-300 retentate fraction on a DEAE-cellulose column resulted in a sharp peak of hydrolase activity emerging from the column at $0.025-0.05 \mathrm{M}-\mathrm{NaCl}$ (Fig. 2). More than $90 \%$ of the activity recovered was present in fractions 3 and 4 . These combined fractions constituted a twofold purification relative to the XM-300 retentate. The specific activity of the most active fraction (3) was increased more than fourfold relative to the XM-300 retentate fraction. In some experiments the peak of CDP-DG hydrolase activity was eluted from the column in fraction 4 rather than fraction 3 , and therefore both were routinely combined.

The pooled fractions were concentrated and freed of excess Triton $\mathrm{X}-100$ by ultrafiltration, using a Diaflo PM-10 membrane in an Amicon model 12 stirred ultrafiltration cell, at less than $40 \mathrm{psi}$. Before ultrafiltration, the pooled fractions were diluted to $30 \mathrm{ml}$ with $10 \mathrm{~mm}$-Tris- $\mathrm{HCl}$ (pH 7.4), containing $30 \%$ ethylene glycol $(\mathrm{w} / \mathrm{v})$ and $10 \%$ ethanol in order to break up the Triton X-100 micelles (Frasch, 1975). To remove remaining detergent, the enzyme was concentrated to $1 \mathrm{ml}$ and diluted to $10 \mathrm{ml}$ with $10 \mathrm{~mm}-\mathrm{Tris}-\mathrm{HCl}(\mathrm{pH} 7.4)$ containing $30 \%$ ethylene glycol $(\mathrm{w} / \mathrm{v})$ and $10 \%$ ethanol, and concentrated again to $1 \mathrm{ml}$. The concentrated enzyme was then washed in the same manner with two 10-ml portions of $1 \mathrm{~mm}$-sodium phosphate buffer ( $\mathrm{pH} \mathrm{7.4)}$ to remove the ethylene glycol and ethanol. The purified enzyme remained unstable in the absence of detergent, and the final enzyme concentrate $(1 \mathrm{ml})$ was made $0.2 \%$ in Triton X-100. More than $80 \%$ of the enzyme activity in the pooled fractions following DEAE-cellulose chromatography was recovered following ultrafiltration and represented a 90-fold enrichment of activity relative to the initial homogenate. The purified enzyme was stable for at least 4

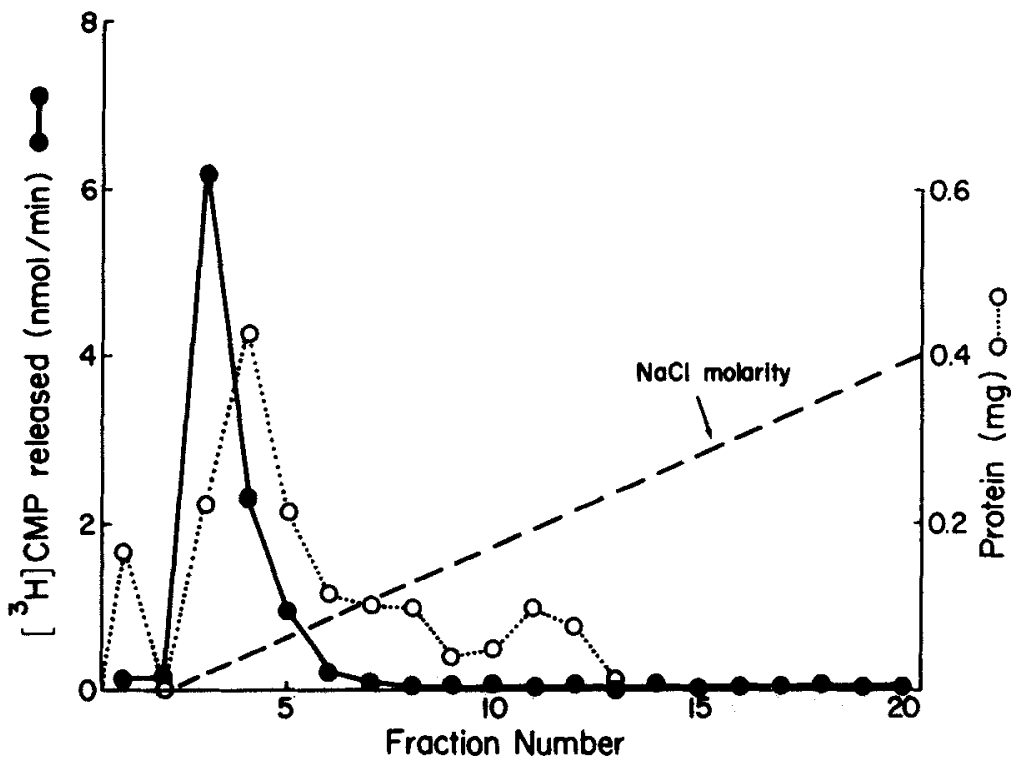

FIG. 2. DEAE-cellulose chromatography of CDP-diglyceride hydrolase. An aliquot of protein $(1.7 \mathrm{mg})$ from the XM-300 ultrafiltration step was applied to a $5 \times 0.5$

o $\mathrm{cm}$ column containing Whatman DE-52, equilibrated with $10 \mathrm{~mm}$-Tris-HCl buffer (pH 7.6) containing $0.2 \%$ Triton $X-100$. After six column washes with the equilibrating buffer, a linear $\mathrm{NaCl}$ gradient $(0$ to $0.4 \mathrm{M}$, in equilibrating buffer) was applied to the column. The flow rate was maintained at $24 \mathrm{ml} / \mathrm{h}$ and $5.6-\mathrm{ml}$ fractions were collected. Fractions 1 to 20 were assayed for CDP-DG hydrolase activity as described in Materials and Methods. 
months at $4^{\circ} \mathrm{C}$. The specific activities of the PM-10 retentate enzymes obtained in separate experiments varied from 22 to $43 \mathrm{nmol} C D P$-dipalmitin hydrolyzed per min per $\mathrm{mg}$ protein.

\section{Identification of Products}

In order to eliminate possible complications due to the presence in the homogenate of nucleotidases and PhA phosphohydrolase activities, product identification was carried out with purified PM-10 retentate fraction. An incubation mixture containing $56 \mathrm{nmol}$ of $\left[{ }^{3} \mathrm{H}\right] \mathrm{CDP}$-dipalmitin was incubated for $4.5 \mathrm{~h}$ at $\mathrm{pH} 4.8$ in the standard enzyme assay mixture. Following addition of the acidified chloroform-methanol and separation of phases, a 0.5 $\mathrm{ml}$ aliquot of the aqueous layer was dried under $\mathrm{N}_{2}$, dissolved in $0.05 \mathrm{ml}$ of $\mathrm{H}_{2} \mathrm{O}$, and subjected to high-voltage electrophoresis at $\mathrm{pH} 4.3$ with CMP, $\mathrm{CDP}$, and cytidine standards. The derivatives were located by UV absorption, cut out, and counted. All of the recovered activity was found in the CMP spot. The organic layer from the extracted incubation mixture was dried under $\mathrm{N}_{2}$, redissolved in chloroform-methanol (2:1), and applied to a TLC plate in solvent system $B$, together with standards of $\mathrm{PhA}$, lyso-PhA, and diacyl glycerol. Areas corresponding to lipid markers were scraped and transferred to Pasteur pipet columns plugged with glass wool. Lipids were eluted with two $5-\mathrm{ml}$ volumes of chloroform/methanol (3:2) and total phosphate was determined. A single lipid phosphorus spot with an $R_{\mathrm{f}}$ of 0.5 was found, which corresponds to that of authentic dipalmitoyl PhA. CDP-DG remains at the origin in this system. With solvent system $A$, the product co-migrated with authentic $\mathrm{PhA}$ with an $\boldsymbol{R}_{\mathrm{f}}$ of 0.83 , while CDP-DG, lyso-PhA, and diacylglycerol had $R_{\mathrm{f}}$ 's of $0.28,0.47$ and 1.0 , respectively. A very faint spot was seen in the lyso-PhA region. Stoichiometry was calculated by comparison of aqueous phosphate released with that lost from the organic phase during a 6-h incubation in which $>90 \%$ of CDP-DG was utilized (theoretical, 1.00; found, 1.07).

\section{Properties of the Purified Enzyme}

The PM-10 retentate fraction displayed normal Michaelis-Menten kinetics towards CDP-dipalmitin in the concentration range $0.023-0.92 \mathrm{mM}$. A $K_{\mathrm{m}}$ value of $45 \mu \mathrm{M}$ was calculated from linear regression analysis of double-reciprocal plots (Fig. 3). The pH optimum was 4.8 (Fig. 4). Neither $\mathrm{K}^{+}$nor $\mathrm{Na}^{+}$ ions (1 $\mathrm{mM}$ ) had a significant effect on the hydrolase, while all divalent cations tested were inhibitory. $\mathrm{Hg}^{2+}$ was most potent, and produced $75 \%$ inhibition, whereas $\mathrm{Mg}^{2+}$ was least inhibitory (16\%). Other ions in order of descending inhibition were

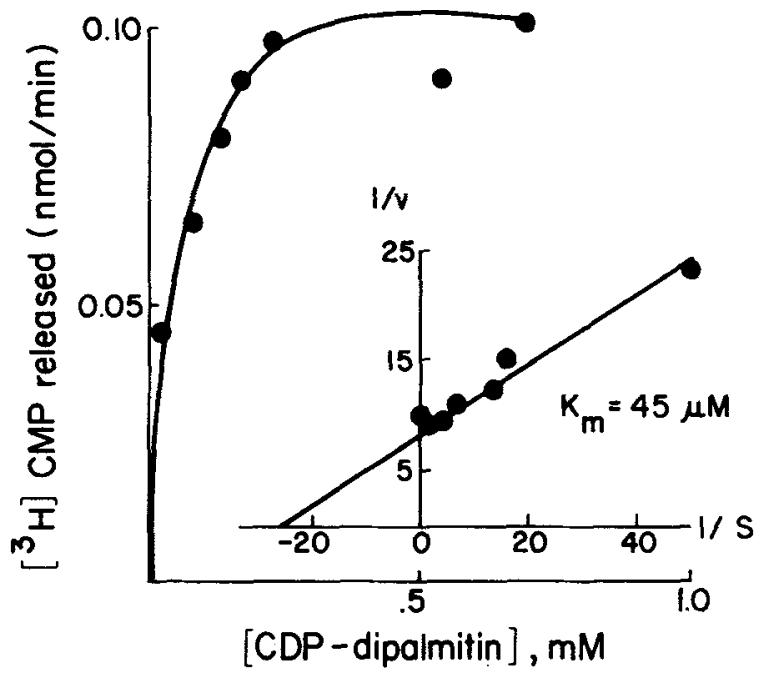

FIG. 3. Effect of concentration of substrate (CDP-dipalmitin) on CDP-diglyceride hydrolase activity. Purified PM-10 retentate enzyme ( $3.3 \mu \mathrm{g}$ protein) was incubated for $30 \mathrm{~min}$ in the presence of different substrate concentrations, in the range 0.02 to $0.69 \mathrm{~mm}$. Nonenzymic release of water-soluble radioactivity was determined at each substrate concentration and subtracted from the observed enzyme rates. A doublereciprocal plot of the data is shown in the inset. The calculated value of the $K_{m}$ is $45 \mu \mathrm{M}$.

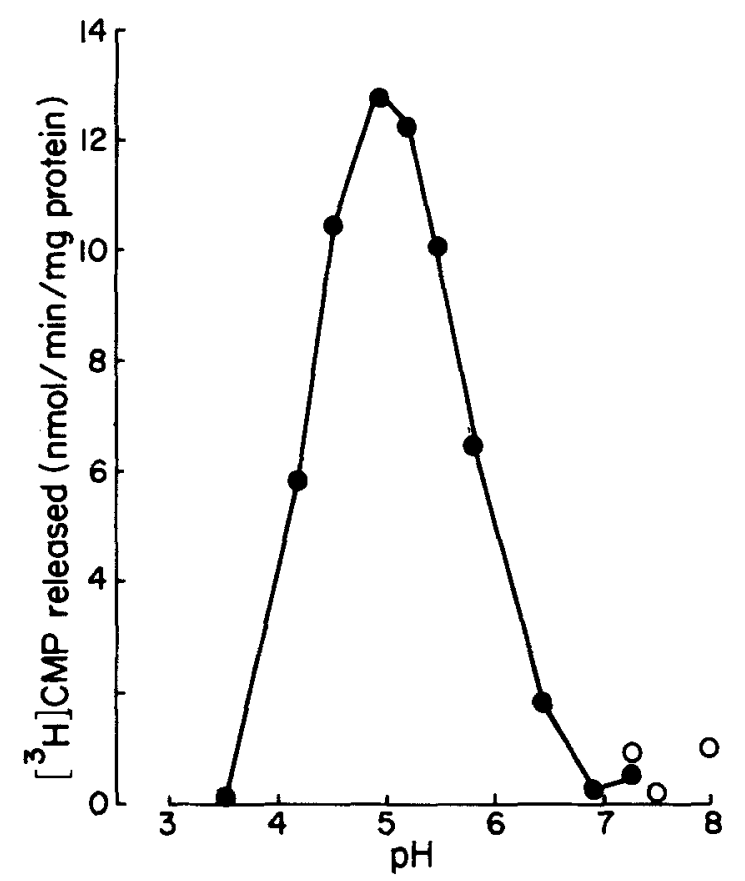

FIG. 4. Effect of pH on CDP-diglyceride hydrolase activity. Enzyme (2.5 $\mu \mathrm{g}$ protein), obtained from pooled fractions 3 and 4 following DEAE-cellulose chromatography, was incubated for $30 \mathrm{~min}$ in the presence of $0.1 \mathrm{M}$-Tris-maleate buffers

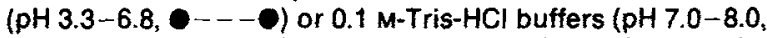
$0---0$ ). Nonenzymic water-soluble radioactivity was determined at each $\mathrm{pH}$ and subtracted from the observed enzyme rates. 
$\mathrm{Mn}^{2+}, \mathrm{Cu}^{2+}, \mathrm{Ca}^{2+}$, and $\mathrm{Zn}^{2+}$. The addition of either 5 mM-EDTA or -EGTA in the absence of added divalent cations did not affect enzyme activity.

\section{Substrate Specificity}

A number of potential substrates and inhibitors were examined with the purified enzyme for their possible effects on CDP-DG hydrolase. Of the liponucleotides, both ACDP-DG and ADP-DG were strongly inhibitory (Table 4). In separate experiments, it was shown that radioactively labeled dCDP-DG was itself hydrolyzed by the enzyme at $20 \%$ the rate observed with CDP-DG. In contrast, CDP-choline, CDP-glycerol, and sodium pyrophosphate were not inhibitory. In view of the inhibition of the enzyme by AMP in the present experiments as well as of the bacterial enzyme (Raetz et al., 1976) structural analogs of this nucleotide were investigated. Both 5'-AMP and 5'-dAMP produced strong inhibition (over $90 \%$ ), while a mixture of 2 and $3^{\prime}$-AMP was less inhibitory. Substitution of the

TABLE 4. Inhibitors of CDP-diglyceride hydrolase activity

\begin{tabular}{|c|c|}
\hline $\begin{array}{l}\text { Compounds producing } \\
>10 \% \text { inhibition }\end{array}$ & Inhibition (\%) \\
\hline dCDP-DG & 85 \\
\hline ADP-DG ${ }^{a}$ & 100 \\
\hline $5^{\prime}-\mathrm{AMP}^{n}$ & 97 \\
\hline 2,d-5'-AMP & 90 \\
\hline 2'-AMP-3'-AMP Mixture & 45 \\
\hline Adenosine 5'-monophosphoramidate & 54 \\
\hline$S^{\prime}-\mathrm{GMP}$ & 55 \\
\hline NADH & 70 \\
\hline Coenzyme A & 71 \\
\hline$\beta, \gamma$-Methylene ATP & 56 \\
\hline Ara-AMP & 89 \\
\hline Ara-CMP & 20 \\
\hline Ara-C & 19 \\
\hline
\end{tabular}

(b)

Compounds Producing $<10 \%$ inhibition

\begin{tabular}{ll}
\hline CDP-choline & Ara-A \\
CDP-glycerol & Ribose-5'-phosphate \\
Sodium pyrophosphate & CMP, IMP \\
$5^{\prime}$-Adenosine monosulfate & Cyclic $3^{\prime} 5^{\prime}$-AMP \\
$\alpha, \beta$-Methylene ATP & Myo-inositol ${ }^{b}$ \\
\hline
\end{tabular}

Purified PM-10 retentate enzyme (approximately $7 \mu \mathrm{g}$ protein) was incubated for 30 or $60 \mathrm{~min}$ in the presence of inhibitors, as indicated. The concentration of CDP-dipalmitin was $0.23 \mathrm{~mm}$ and that of the inhibitors was $2.3 \mathrm{~mm}$.

a Equimolar concentrations of inhibitor and substrate still produced $90 \%$ inhibition.

${ }^{b}$ Also tested at $1.0 \mathrm{~mm}$. In addition, enzyme and substrate were incubated with inositol and $\mathrm{Mg}^{2+}$ at $\mathrm{pH} \mathrm{8.3.} \mathrm{No} \mathrm{CDP-DG:}$ inositol transferase activity was detected.
5 '-phosphate by sulfate destroyed the inhibitory effect. While ATP produced some inhibition, the $\alpha, \beta$-methylene derivative was not inhibitory, a result suggesting that some degradation of ATP to AMP may account for the observed inhibition. The $\beta, \gamma$-methylene derivative of ATP, which is easily hydrolyzed to AMP, was inhibitory. Ara-C, a potential chemotherapeutic agent (Raetz et al., 1977) was inhibitory, as were both ara-CMP and araAMP. Ara-A was without effect. Adenosine 5'- $O$ thiomonophosphate was as effective an inhibitor as AMP.

\section{Tissue Distribution of CDP-DG Hydrolase}

CDP-DG hydrolase activities were detected in dialyzed homogenates of all organs tested. Spleen and brain extracts had comparable specific activities, while lung, kidney, heart, and liver were only slightly less active.

\section{DISCUSSION}

The data presented are consistent with the presence in eukaryotic tissues of CDP-DG hydrolase activity. The brain enzyme appears to be lysosomal as judged from its distribution in subcellular fractions, its release upon freeze-thaw treatment, and its acidic $\mathrm{pH}$ optimum. It is unlikely that the observed activity could be accounted for by the action of other enzymes of CDP-DG metabolism. CTP:PhA cytidyl transferase purified from yeast (Belendiuk et al., 1978) or $E$. coli (Langley and Kennedy, 1978) has no CDP-DG hydrolase activity. In addition, the brain CDP-DG hydrolase preparation is not affected by the addition of inorganic pyrophosphate and has no divalent cation requirement. The lack of a metal requirement, the distribution of the hydrolase in brain subcellular fractions, and the observed $\mathrm{pH}$ optimum also rule out a role for CDP-DG:inositol transferase in the observed hydrolytic activity. Furthermore, the addition of 1 mM-inositol did not stimulate release of watersoluble radioactivity. The observed lysosomal distribution also speaks against the possibility that the observed activity can be attributed to a nonspecific nucleotide pyrophosphatase, since this class of enzymes is characterized by a somewhat alkaline $\mathrm{pH}$ optimum, a localization in microsomal and plasma membrane fractions and frequently, but not invariantly, a divalent cation requirement (Schliselfeld et al., 1965; Bischoff et al., 1975). The brain CDP-DG hydrolase was also unaffected by the presence of a 10-fold excess of CDP-choline.

The conversion of CDP-DG to phosphatidylinositol (PhI) catalyzed by CDP-DG:inositol transferase has been demonstrated to be reversible (Petzold and Agranoff, $1965 ; 1967)$. The reverse reaction, 
coupled with CDP-DG hydrolase, yields a phospholipase D-like conversion of $\mathrm{PhI}$ to $\mathrm{PhA}$ and myo-inositol:

$$
\text { Net } \quad \begin{gathered}
\mathrm{PhI}+\mathrm{CMP} \leftrightharpoons \mathrm{CDP}-\mathrm{DG}+\text { myo-inositol } \\
\mathrm{CDP}-\mathrm{DG}+\mathrm{H}_{2} \mathrm{O} \rightarrow \mathrm{CMP}+\mathrm{PhA}
\end{gathered}
$$

A phospholipase $\mathrm{D}$ action in the pancreas has been invoked to explain a "phospholipid labeling effect," i.e., increased labeling of PhI and $\mathrm{PhA}$ from ${ }^{32} P_{i}$ (Hokin-Neaverson et al., 1978). In pancreas, unlike brain, a net decrease in the amount of $\mathrm{PhI}$ and commensurate increase in PhA is seen following addition of cholecystokinin (pancreazymin) or acetylcholine. Different intracellular localizations and $\mathrm{pH}$ optima for the hydrolase and transferase, however, render this hypothesis less attractive.

The brain enzyme differs from bacterial CDP-DG hydrolase in a number of ways. The bacterial enzyme is not reported to have an acidic pH optimum, is inactive against dCDP-DG, and is not inhibited by the deoxy-liponucleotide (Raetz, 1972). In contrast, the present studies indicate that the brain enzyme cleaves dCDP-DG, and CDP-DG hydrolysis is blocked by the presence of dCDP-DG.

dCDP-DG is found in bacteria in equimolar amounts with CDP-DG (Raetz et al., 1976). The CTP:PhA cytidyl transferase of bacteria accepts dCTP and CTP equally well, and both nucleotides can be utilized to form bacterial lipids. Since there is much more CTP available in bacteria than dCTP, it has been suggested that the differential action of the hydrolase may be responsible for the unexpectedly high levels of dCDP-DG found in bacteria. The significance of the two precursors, seemingly equally suitable, is unknown. In yeast, the CTP:PhA cytidyl transferase accepts only CTP as a substrate and hence dCDP-DG is not found. In liver and brain, both triphosphates are accepted, but only CDP-DG has so far been isolated from tissue. The absence of dCDP-DG in animals can be accounted for by the relatively low amount of dCTP available for dCDP-DG synthesis, since the hydrolase in brain (unlike bacteria) can utilize both CDP-DG and dCDP-DG as substrates.

Of the various enzymes of liponucleotide metabolism, those of synthesis appear rate-limiting, a concept supported by the low steady state levels of liponucleotides in sources so far examined. Hydrolase rates are generally of the order of, or greater than, lipid biosynthetic reactions (Carter and Kennedy, 1966; Petzold and Agranoff, 1967). The highly specific inhibition by AMP in both bacterial and mammalian enzymes is unexplained, but may be related to a regulatory mechanism.

The presence of CDP-DG hydrolase in brain was postulated previously by Eliasson et al. (1972), who found that brain from rabbits with a hereditary ataxia was inefficient in producing $\mathrm{PhI}$ from added
CDP-DG precursor. It is possible that the pathological changes in the animals led to increased lysosomal content secondary to degenerative changes and, hence, to increased CDP-DG hydrolase activity.

Liponucleotides have been proposed as convenient forms for the introduction of chemotherapeutic agents. For example, ara- $\mathrm{C}$ has been introduced into experimental animals in the form of araCDP-DG liposomes (Raetz et al., 1977). It is proposed that the micelles are readily picked up by cells and then cleaved by CDP-DG:inositol transferase to form ara-CMP and phosphatidylinositol, thus additionally bypassing the nucleoside kinase step, thought to be rate-limiting. From the present experiments, it appears more likely that the araCDP-DG is cleaved by CDP-DG hydrolase. If the micelles are picked up by endocytosis, they are likely to come in contact with lysosomal enzymes immediately upon entry into the cell. Although the activity of mammalian CDP-DG hydrolase against ara-CDP-DG is as yet unknown, this possibility should be given consideration in view of the low specificity of the mammalian enzyme.

Note added in proof: In subsequent experiments, the apparent $K_{\mathrm{M}}$ toward CDP-dipalmitin has varied from 64 to $127 \mu \mathrm{M}$, possibly reflecting the lipid content in a given preparation of partially purified enzyme.

\section{ACKNOWLEDGMENT}

This research was supported by NIH Grant NS 15413. S.K.F. was supported by NIMH Training Grant MH07417. We are indebted to Mr. Matthew Lynn for the preparation of labeled substrates.

\section{REFERENCES}

Agranoff B. W. and Suomi W. (1963) Cytidine diphosphate-DLdipalmitin. Biochem. Prep. 10, 47-51.

Ames B. N. and Dubin D. T. (1960) The role of polyamines in the neutralization of bacteriophage deoxyribonucleic acid. $J$. Biol. Chem. 235, 769-775.

Belendiuk G., Mangnall D., Tung B., Westley J., and Getz G. S. (1978) CTP-phosphatidic acid cytidyltransferase from Saccharomyces cerevisiae. J. Biol. Chem. 253, 4555-4565.

Bensadoun A. and Weinstein D. (1976) Assay of proteins in the presence of interfering materials. Anal. Biochem. 70, $241-250$.

Bischoff E., Tran-Thi T., and Decker K. F. A. (1975) Nucleotide pyrophosphatase of rat liver. Eur. J. Biochem. 51, 353-361.

Carter J. R. and Kennedy E. P. (1966) Enzymatic synthesis of cytidine diphosphate diglyceride. J. Lipid Res. 7, 678-683.

Cotman C. W. and Matthews D. A. (1971) Synaptic plasma membranes from rat brain synaptosomes: Isolation and partial characterization. Biochim. Biophys. Acta 249, 380-394.

Dittmer J. C. and Lester R. L. (1964) A simple, specific spray for the detection of phospholipids on thin-layer chromatograms. J. Lipid Res. 5, 126-127.

Donnelly C. H., Richelson E., and Murphy D. L. (1976) Properties of monoamine oxidase in mouse neuroblastoma NIE115 cells. Biochem. Pharmacol. 25, 1639-1643. 
Eliasson S. G., Scarpellini J. D., and Fox R. R. (1972) Metabolism of cytidine diphosphate diglyceride in ataxic rabbit brain. Arch. Neurol. 27, 535-539.

Ellman G. L., Courtney K. D., Andres V., and Featherstone R. M. (1961) A new and rapid colorimetric determination of acetylcholinesterase activity. Biochem. Pharmacol. 7, $88-95$.

Fewster M. E., Burns B. J., and Mead J. F. (1969) Quantitative densitometric thin-layer chromatography of lipids using copper acetate reagent. J. Chromatogr. 43, 120-126.

Fonnum F. (1975) A rapid radiochemical method for the determination of choline acetyltransferase. $J$. Neurochem. 24, 407-409.

Frasch C E. (1975) Removal of detergents by ultrafiltration. Dialog (Amicon Corp., Lexington, Mass.) 7(2), 1-3.

Geiger P. J. and Bessman S. P. (1972) Protein determination by Lowry's method in the presence of sulphydryl reagents. Anal. Biochem. 49, 467-473.

Hajra A. K., Seguin E. B., and Agranoff B. W. (1968) Rapid labeling of mitochondrial lipids by labeled orthophosphate and adenosine triphosphate. J. Biol. Chem. 243, 1609-1616.

Hawthorne J. N. and Pickard M. R. (1979) Phospholipids in synaptic function. $J$. Neurochem. 32, 5-14.

Hokin L. E. and Hokin M. R. (1955) Effects of acetylcholine on the turnover of phosphoryl units in individual phospholipids of pancreas slices and brain cortex slices. Biochem. Biophys. Acta 18, 102-110.

Hokin-Neaverson M., Sadeghian K., Harris D. W., and Merrin J.S. (1978) The mechanism of stimulated phosphatidylinositol breakdown, in Cyclitols and Phosphoinositides (Wells W. W. and Eisenberg F., eds) pp. 349-359. Academic Press, New York.

Hoover D. B., Muth E. A., and Jacobowitz D. M. (1978) A mapping of the distribution of acetylcholine, choline acetyltransferase and acetylcholinesterase in discrete areas of rat brain. Brain Res. 153, 295-306.

Langley K. E. and Kennedy E. P. (1978) Partial purification and properties of CTP:phosphatidic acid cytidyltransferase from membranes of Escherichia coli. J. Bacteriol. 36, 85-95.

Lisman J. J. W., DeHaan J., and Overdijk B. (1978) Isolation of lysosomes from brain tissue. Biochem. J. 178, 79-87.
Michell R. H. (1975) Inositol phospholipids and cell surface receptor function. Biochim. Biophys. Acta 415, 81-147.

Petzold G. L. and Agranoff B. W. (1965) Studies on the formation of CDP-diglyceride. Fed. Proc. 24, 476.

Petzold G. L. and Agranoff B. W. (1967) Biosynthesis of cytidine diphosphate diglyceride by embryonic chick brain. J. Biol. Chem. 242, 1187-1191.

Porteus J. W. and Clark B. (1965) The isolation and characterization of subcellular components of the epithelial cells of rabbit small intestine. Biochem. J. 96, 159-171.

Raetz C. R. H. (1972) Biogenesis of Membrane Phospholipids in Escherichia coli. Ph.D. Thesis, Harvard University.

Raetz C. R. H., Hirschberg C. B., Dowhan W., Wickner W. T., and Kennedy E. P. (1972) A membrane-bound pyrophosphatase in Escherichia coli catalyzing the hydrolysis of cytidine diphosphate-diglyceride. J. Biol. Chem. 247, 2245-2247.

Raetz C. R. H., Dowhan W., and Kennedy E. P. (1976) Partial purification and characterization of cytidine 5'-diphosphate-diglyceride hydrolase from membranes of Escherichia coli. J. Bacteriol. 125, 855-863.

Raetz C. R. H., Chu M. Y., Srivastava S. P., and Turcotte J. G. (1977) A phospholipid derivative of cytosine arabinoside and its conversion to phosphatidylinositol by animal tissue. Science 196, 303-305.

Rittenhouse H. G., Seguin E. B., Fisher S. K., and Agranoff B. W. (1980) CDP-diglyceride hydrolase in guinea-pig brain. Trans. Am. Soc. Neurochem. 11, 138.

Schacht J. and Agranoff B. W. (1972) Effect of acetylcholine on labeling of phosphatidate and phosphoinositides by ${ }^{32} \mathrm{P}$ orthophosphate in nerve ending fractions of guinea-pig cortex. J. Biol. Chem. 247, 771-777.

Schliselfeld L. H., Van Eys J., and Touster O. (1965) The purification and properties of a nucleotide pyrophosphatase of rat liver nuclei. J. Biol. Chem. 240, 811-818.

Thompson W. and MacDonald G. (1975) Isolation and characterization of cytidine diphosphate diglyceride from beef liver. J. Biol. Chem. 250, 6779-6785.

Thompson W. and MacDonald G. (1976) Cytidine diphosphate diglyceride of bovine brain. Eur. J. Biochem. 65, 107-111. 